\title{
ECOLOGICAL ANALYSIS OF LITERACY IN RAJASTHAN: AN APPLICATION IN SOCIAL GIS
}

\author{
Urmi Sharma ${ }^{1}$, Seema Jalan ${ }^{2}$ and Purnima Singh ${ }^{3}$ \\ ${ }^{1}$ Assistant Professor, ${ }^{2}$ Professor, \\ Department of Geography, MLS University, Udaipur (Rajasthan) India \\ ${ }^{3}$ Assistant Professor, Govt. Meera Girls' College, Udaipur (Rajasthan) India \\ Email: seemajalan1@gmail.com
}

\begin{abstract}
Literacy, the ability to 'read' and 'write' in any language, provides the basal stratum for the multi-level educational pyramid, a major component of Human Development Index. The overall literacy rate of Rajasthan is 66.11 percent as per Census 2011 which has increased by 5.70 percent over 2001. The dismal status of literacy in the State is manifest in its $33^{\text {rd }}$ position among all the States and Union Territories in the country. It also lags behind on other parameters, viz. male, female, rural and urban literacy significantly. The present study undertakes a multifaceted investigation of the status and spatial patterns of literacy in Rajasthan based on the Census data of 2011 at tehsil level. A robust methodology including cartographic, statistical and geospatial tools has been employed to identify priority areas. Spatial variations in levels of literacy have been mapped and analysed in context of the socioeconomic characteristics of the region. Results reveal high spatial variation in literacy with a clear north-east and south-west divide in the State. Western, southern and south-western parts of the State form a cold spot for rural-urban literacy hence need top priority in policy making.
\end{abstract}

Key words: Literacy Rate, Social GIS, Hot Spot Analysis

\section{Introduction}

The study of human behaviour, their attitudes and their responses to their natural and cultural milieu have been the focal theme of human geography. The concept of 'Space' i.e. the spatial context or geographical location, is of overarching significance for explaining social phenomenon effectively revealing the complex relationship between various factors, directly or indirectly affecting them. "One of the strongest arguments for looking at society through a spatial lens-through maps, GIS, and spatial analysis-is that it provides observations with context: processes can be examined in their geographic settings" (ESRI July, 2009). The significance of geospatial techniques to infer solutions to social problems and other socioeconomic aspects is a novel field of research. GIS is being used to analyse spatial patterns of human health (Shekhawat et. al. 2011) and concentration of SC/ST population for purpose of electoral delimitation by Jalan (2015). Geographical Information System (GIS) with its vast capabilities of dynamic mapping, visualization, integration, spatial analysis and modelling enables more robust analysis and unique insights into geographical underpinnings of socioeconomic phenomenon. It has also facilitated an interdisciplinary approach towards researches specifically dealing with spatial phenomenon. Application of GIS in social science research is commonly termed as 'Social GIS'.

Literacy is a significant milestone in the developmental journey of a nation as it acts as a yardstick for its socio-economic progress. According to census 2011 Rajasthan has a dismal status in literacy. Ranking $33^{\text {rd }}$ among all the States and Union Territories with total literacy rate at 66.11 percent only above Arunachal Pradesh (65.4 percent) and Bihar (61.8 percent) (Census 2011). Literacy rates in the State are below national averages in all categories viz. total, rural, urban, male and female literacy. It also accounts for the lowest female literacy in the country. The challenge is to elevate the status of literacy in the State with paramount focus on regions which are lagging and simultaneous bridging of the disparities. For effective implementation of mitigation measures and policies, understanding the regional variation and identification of priority areas having lowest literacy and highest regional disparity is imperative. Various studies have explored the spatial patterns and trends of literacy rates for different parts of the country including Rajasthan. Recent among these are by Chand (2015), Sharma (2015), 
Ram (2014), Chitragar \& Hurakadli (2013), Sangwan et al. (2014), Zaidi, and Kundu and Rao (1982). The underlying geographical perspective of these studies is to investigate the regional (rural - urban) differential, gender disparity, caste and class bias in levels of literacy. The socioeconomic aspects of population and their relationship with literacy have also been investigated (Singh, 2014). Heretofore traditional statistical tools and choropleths have been used to map the spatial phenomena. The insights obtained using choropleth techniques are not very reliable since the patterns are prone to vary by changes in class categories. GIS based spatial statistical techniques are capable of providing significant insights into the distribution of the phenomenon unaffected by the class categories. These tools incorporate 'space' into analysis, unlike traditional methods and open a completely new world of exploring and answering complex realities by identifying statistically significant clusters (hot spots and cold spots). These clusters ought to be basis of identifying priority for regional policy making. Spatial analytical techniques in geospatial domain have been used to analyse spatial patterns of crime by Ansari \& Kale (2014), road accidents by Aghajani et. al (2017). Present paper undertakes ecological analysis of spatial patterns of literacy in the state of Rajasthan at tehsil level based on Census 2011 data. Status and regional variations in literacy have been analysed in socio-economic context. The study also explores the application of spatial analytical tools implemented in GIS to identify the priority areas for policy formulation and decision making.

\section{Study Area}

Rajasthan is the largest state of India administratively divided into 33 districts and 244 tehsils As per Census 2011, the total population of the State is 6.86 crores which is approximately 5.6 percent of the country's total population. Major concentration of the population is in eastern part of the state as around 61 percent of its total area is desert in the west. The urban population is relatively more concentrated in the eastern half of the State. Despite a large population base the total literacy rate of Rajasthan is pegged at 66.11 percent. Wide disparities in rural-urban and male-female literacy rates are witnessed for Rajasthan with urban literacy as 79.7 percent while rural literacy being 61.4 percent. Similarly, overall male literacy in the State is 79.2 percent whereas its female counterpart is just 52.1 percent.

\section{Methodology}

Entire analysis is based on Census 2011 data. Standard census definitions for computation of total, rural, urban, male and female literacy have been followed. All relevant variables have been joined to tehsil map in GIS environment and choropleth maps have been prepared to map spatial patterns of variation in literacy levels. Spatial statistics implemented in GIS has been employed for further analyses. Factor analyses and multiple regression have been used to model the socio-economic correlates of literacy. Geospatial data generation and analysis have been performed in ArcGIS version 10.2.2. SPSS version 23 has been used for statistical analysis. Major steps of methodological workflow subsequent to data generation may be summarized as under:

\section{Identifying Clusters of Low and High values of Literacy}

Using Anselin's Local Moran's I and Getis Ord Gi' statistics, statistically significant clusters of high and low total literacy have been demarcated. Anselin's Local Moran's I (Cluster and Outlier Analysis) emphasizes on how much each feature (spatial unit) is similar or dissimilar to its neighbours (Mitchell, 2009). The clusters of similar values (high-high; low-low) and dissimilar values (high-low; low-high) have been obtained. Clusters of dissimilar values highlight the specific socio-economic processes operating at local scale which need tailored solutions to the problems. Getis Ord Gi ${ }^{*}$ statistics (Hot Spot Analysis) identifies areas of statistically significant concentration of high and low values called as hot spots and cold spots respectively (Mitchell, 2009). These hot and cold spots are interpreted in terms of clusters of high and low values respectively with statistically significant difference from the regional mean. Cold spots (of literacy in present context) indicate specific factors and challenges operating at regional scale and demand highest priority in policy making in line with these underlying factors.

\section{Quantifying Socio-economic Correlates of Literacy}

Thirteen variables relating to demographic composition, literacy rates of population sub-groups, rural-urban character and occupational structure of the tehsil have been selected to understand the relative importance of various socio-economic correlates and determinants of literacy (Table 1). In case of variables with perfect correlation, viz. proportion of male and female 
population, rural and urban population of a tehsil, only one of the pair of variables has been chosen- including female population and rural population in the model. Owing to purely rural character of 64 tehsils, urban literacy (having null values for these tehsils) has been excluded from the model. Exploratory factor analysis has been performed for identifying the underlying uncorrelated socio-economic dimensions. Principal Component method for extraction and Varimax with Kaiser normalization method for rotation of extracted components resulted in 5 factors (with eigen values greater than 1). Relative importance of various socio-economic dimensions in explaining the spatial variability of literacy has been quantified using multiple regression with factor scores of extracted components as independent variables and total literacy as dependent variable.

Table 01: Socio-Economic Variables Input to Factor Analysis

\begin{tabular}{|c|l|c|}
\hline$\#$ & Variable & Abbreviation \\
\hline 1 & Rural population as percentage of total population of the tehsil & R_P \\
\hline 2 & Female population as percentage of total population of the tehsil & F_P \\
\hline 3 & Sex Ratio & S_R \\
\hline 4 & Male literacy rate & M_L \\
\hline 5 & Female literacy rate & F_L \\
\hline 6 & Rural literacy rate & R_L \\
\hline 7 & Scheduled caste population as percentage of total population of the tehsil & SC \\
\hline 8 & Scheduled tribe population as percentage of total population of the tehsil & ST \\
\hline 9 & Working population as percentage of total population of the tehsil & W_P \\
\hline 10 & Cultivators as percentage of total working population & CL \\
\hline 11 & Agricultural labourers as percentage of total working population & AL \\
\hline 12 & Household industry workers as percentage of total working population & HH \\
\hline 13 & Percentage of other workers to total working population & OTH \\
\hline
\end{tabular}

\section{Results and Discussion}

Literacy in the State exhibits clear spatial patterns with notable spatial divide in level of overall literacy. Regions of high and low literacy correspond with district boundaries which underline regional disparities in level of socio-economic development in the State at district level.

\section{Spatial Patterns of Total Literacy}

Mean total literacy in the State at tehsil level is 63.38 percent with a standard deviation of 7.92 percent and coefficient of variation of 12.49 percent. Maximum and minimum literacy occurs in Jaipur (Jaipur) (82.68 percent) and Kotra (Udaipur) tehsils (26.57 percent) respectively. Figure 1 and 2 ( $a$ to $d$ ) illustrate various aspects of distribution of literacy rates across tehsils. Table 2 summarizes the regional distribution of tehsils across the scale. Only two tehsils -Kotra and Lasadiya (both are part of Udaipur District) - have exceptionally low literacy (below 40 percent) (Figure 1a).

Figure 01: Distribution of Literacy (a) Box Plot (b) Distribution of Tehsils Across Various Levels of Literacy

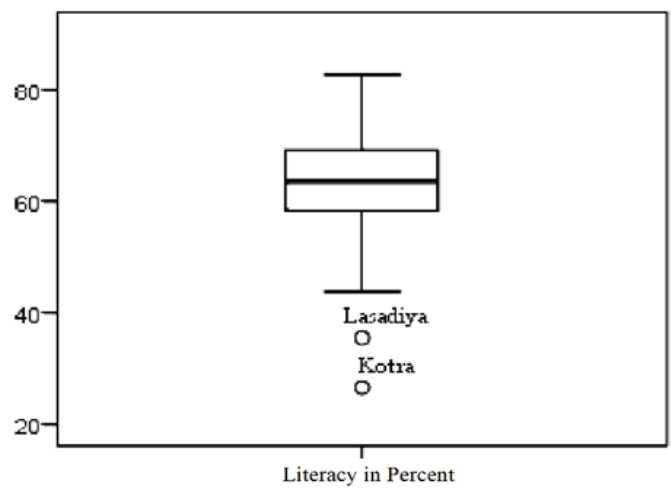

(a)

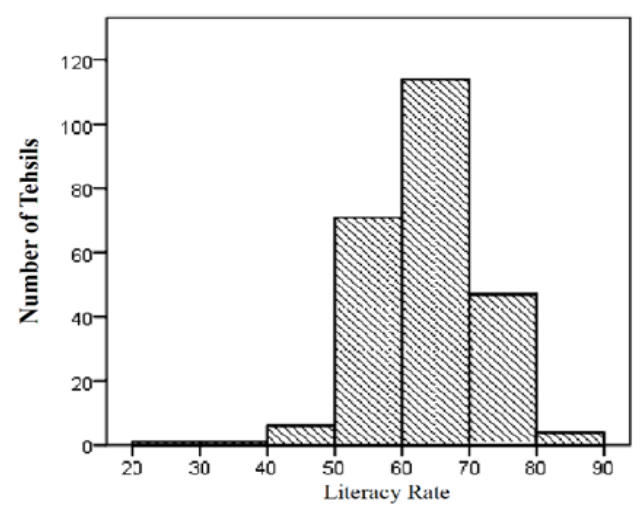

(b) 
The overall distribution of literacy is approximately normal with small negative skewness $(-0.523)$ and kurtosis as 1.69 . Marked variation exists in inter-tehsil level of literacy with majority of the tehsils having literacy ranging between 50 to 80 percent with a few having extremely high or low literacy levels (Figure 1b). Nevertheless, it is not a very promising scenario as only 20 percent of the tehsils have literacy rates above 70 percent which can be accepted as a minimum desirable level at par with the national average (Table 2). Figure $2 a$ shows distribution of total literacy rate across the tehsils. Figure $3 b$ shows the spatial variation from tehsil level means in terms of z-scores. Results of cluster and outlier analysis and hot spot analysis have been shown in Figure $2 c \& d$ respectively. Levels of total literacy manifest a clear north-east and south west divide wherein the tehsils in northern and north-eastern parts of the State have literacy higher than the average. On the other hand, western and south-western parts of the State invariably have below average literacy.

Another notable feature of distribution of total literacy is co-occurrence of high/low literacy pockets. A contiguous region comprising tehsils of Jhunjhunu, Sikar, western parts of Jaipur and Alwar districts form a significant hotspot representing spatial concentration and cooccurrence of tehsils with similarly high levels of literacy (Figure $2 c$ ) wherein the overall literacy is invariably above 70 percent. Two hot spots comprising tehsils of Bharatpur and Sriganganagar districts indicate high levels of literacy in the entire surrounding region (Figure 2d). Similar hot spot exists in south-eastern part of the State comprising tehsils of Kota and western part of Baran districts. Highest literacy has been recorded in Jaipur and Sanganer (Jaipur district), Ladpura (Kota district) and Ajmer (Ajmer district) tehsils having more than 80 percent total literacy which can be attributed to their urban character. Some tehsils comprising district headquarters viz. Jodhpur, Bikaner, Bhilwara and Girwa also have relatively high literacy rates.

Occurrence of contiguous cold spot of total literacy comprising tehsils of western, southwestern and southern districts underlines the dismal state of literacy in the entire region. The situation is most grave in region comprising Jaisalmer, Barmer, Jalor and Sirohi districts (Figure $3 d$ ) wherein the overall literacy hovers around a dismal 40 to 50 percent. A significant cold spot also covers large contiguous region in eastern part of Udaipur and Dungarpur, Banswara and Pratapgarh districts; and scattered regions in Bhilwara and Jhalawar districts which reveal lowest levels of literacy in southern and western Rajasthan.

Table 02: Total Literacy Rates at Tehsil Level in Rajasthan and their Main Regions

\begin{tabular}{|c|c|c|l|}
\hline$\#$. & $\begin{array}{c}\text { TLR } \\
(\%)\end{array}$ & $\begin{array}{c}\text { No. of } \\
\text { Tehsils }\end{array}$ & \multicolumn{1}{|c|}{ Main Regions } \\
\hline 1 & $20-30$ & 1 & (Kotra $)$ Udaipur \\
\hline 2 & $30-40$ & 1 & (Lasadiya) Udaipur \\
\hline 3 & $40-50$ & 6 & $\begin{array}{l}\text { Southern and south-western districts of Jalor, Sirohi, Banswara, Barmer } \\
\text { and Pratapgarh }\end{array}$ \\
\hline 4 & $50-60$ & 70 & $\begin{array}{l}\text { Major tehsils of Jaisalmer, Bikaner, Jodhpur, Barmer, Sirohi, Jalore and } \\
\text { scattered tehsils of central, southern and south-eastern regions }\end{array}$ \\
\hline 5 & $60-70$ & 115 & $\begin{array}{l}\text { Clusters of these tehsils are confined to Ganganagar, Hanumangarh, } \\
\text { Churu, Nagaur and Tonk, Dausa, Karauli, Dhaulpur, Sawai Madhopur } \\
\text { districts mainly in eastern half of the State }\end{array}$ \\
\hline 6 & $70-80$ & 47 & $\begin{array}{l}\text { North-eastern and south-eastern regions with scattered tehsils of } \\
\text { Jodhpur, Bikaner, Pali, Bhilwara and Girwa being district headquarters } \\
\text { of their respective districts. }\end{array}$ \\
\hline 7 & $80-90$ & 4 & \begin{tabular}{l} 
Countable few tehsils of Ajmer, Jaipur and Kota districts \\
\hline
\end{tabular} \\
\hline
\end{tabular}

Source: Directorate of Census Operations Rajasthan, Report 2011

${ }^{\dagger}$ Total Literacy Rate *Names in italics are tehsil names

\section{Ecological Analysis of Spatial Patterns of Literacy}

Table $3(a$ to $c)$ summarize the results of factor analysis. Table $3 a$ shows the extracted rotated components with eigen value greater than 1 . Table $3 b$ shows the variable groups having factor loadings higher than 0.4 on individual factors. Socio-economic dimensions underlying the variables grouping on various factors have been identified in Table $3 c$. Robustness of the model is manifest in the variance explained. The five components explain 88.3 percent of variance in the data. 
Factor loading is the correlation between a variable and a factor. Higher factor loadings indicate that a variable is closely associated with the factor. Based on scores greater than 0.40 , Factor 1 has been identified as Rurality Index. R_P, W_P and CL load highly positively on the factor while $\mathrm{HH}$ and OTH load highly negatively. The variable combination is representative of rural character of a region. Moderate negative factor loading of female literacy is suggestive of widespread female illiteracy in rural areas. Factor 2 correlated highly positively with $M \_L, F \_L$ and $R \_L$. These represent regional and gender aspects of literacy. Factor 3 represents female concentration in the tehsils with extremely high positive loadings ( $>0.95$ ) of F_P and S_R. SC and ST load together on Factor 4 with high positive and negative loadings respectively indicating that Factor 4 is a scale measure of social backwardness. With AL loading at 0.956 and moderate negative loading of CL, Factor 5 is an index of agricultural poverty of the region.

Figure 02: Distribution of total literacy rates at tehsil level (a) Total literacy, (b) Z-Scores of total literacy, (c) Anselin's Local Moran's I and (d) Getis-Ord Gi values rendered according to statistical significance

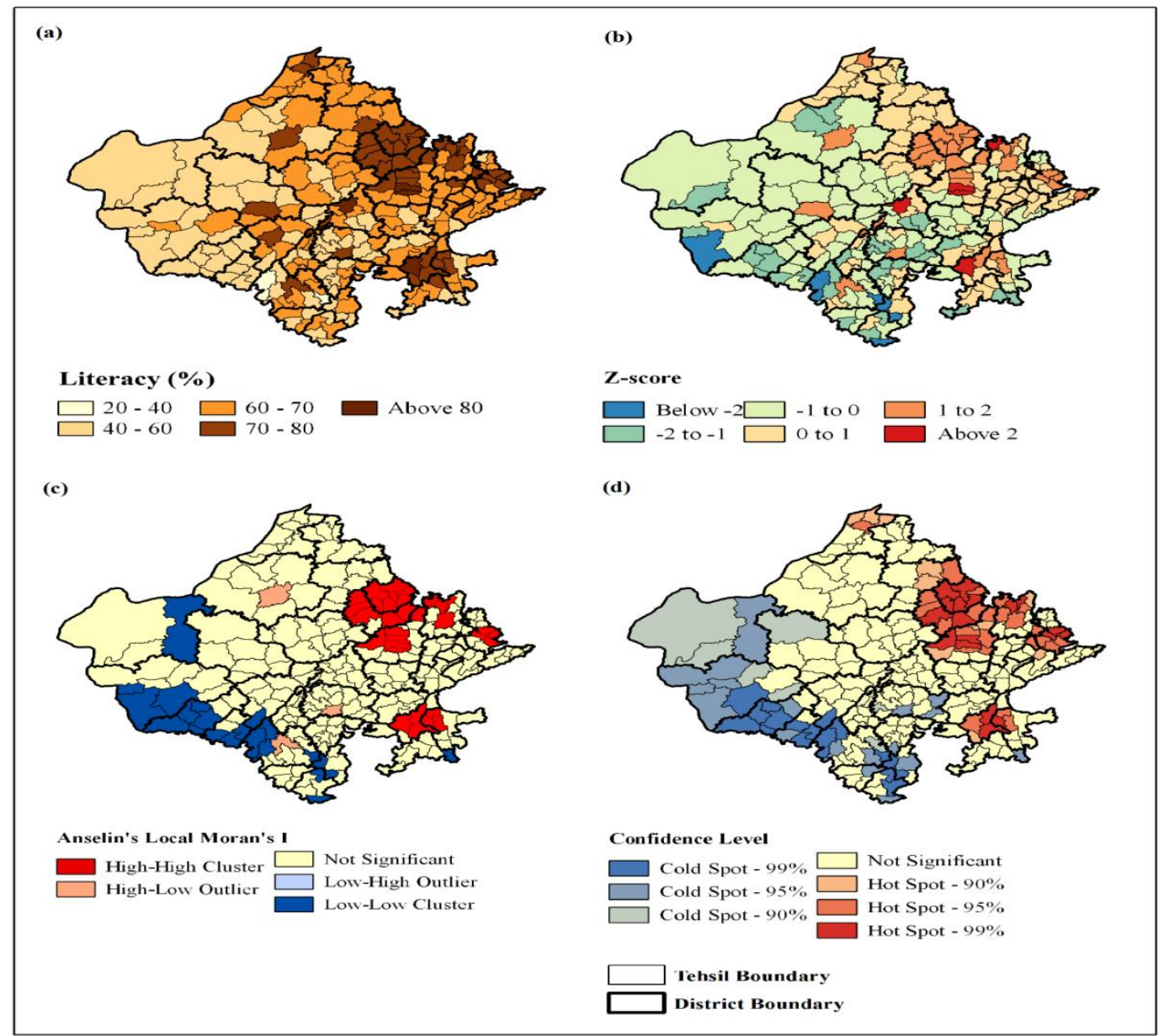

\section{Rurality Index}

Figure $3 a$ shows the distribution of factor scores of rurality index thereby indicating the spatial variation in level of urbanization in the region. Positive factor scores represent areas with larger proportion of rural population with larger work participation rate and agricultural economy. On the other hand, negative factor scores indicate higher proportion of urban population at tehsil level with larger majority engaged in non-agricultural- household and other occupations. Major part of the study area is predominantly rural. Most urbanized tehsils are the ones comprising district headquarters. Remaining parts of the state do not have any significant urban clusters. Sikar, Nagaur, Pali, Sirohi, eastern part of Jalore district, western part of Ajmer and central part of Jaipur districts comprise a continuous belt along the foothills of the Aravalis which scores low on the index. Another region comprises parts of Hadoti region and Chittaurgarh district. 
Table 03: Results of factor analysis (a) Extracted components with eigen values greater than 1 (b) Rotated component matrix and factor loadings, and (c) Interpretation of extracted components.

(a)

\begin{tabular}{|c|c|c|c|}
\hline \multirow{2}{*}{ Component } & \multicolumn{3}{|c|}{ Rotation Sums of Squared Loadings } \\
\cline { 2 - 4 } & Total & \% of Variance & Cumulative \% \\
\hline 1 & 3.698 & 28.445 & 28.445 \\
\hline 2 & 2.764 & 21.263 & 49.708 \\
\hline 3 & 2.096 & 16.119 & 65.827 \\
\hline 4 & 1.620 & 12.463 & 78.291 \\
\hline 5 & 1.297 & 9.981 & 88.271 \\
\hline
\end{tabular}

(b)

(c)

\begin{tabular}{|l|c|c|c|c|c|}
\hline & \multicolumn{5}{|c|}{ Component } \\
\cline { 2 - 6 } Variable & 1 & 2 & 3 & 4 & 5 \\
\hline R_P & .826 & & .967 & & \\
F_P & & & .967 & & \\
S_R & & .904 & & & \\
M_L & & .822 & & & \\
F_L & -.454 & .942 & & .860 & \\
S_L & & & & -.855 & \\
ST & & & & & -.437 \\
W_P & .738 & & & & .956 \\
CL & .852 & & & & \\
AL & -.767 & & & & \\
HH & -.904 & & & & \\
OTH & & & & & \\
\hline
\end{tabular}

\begin{tabular}{|c|l|l|}
\hline Components & Variables (Sign of factor loading) & \multicolumn{1}{|c|}{ Index } \\
\hline F1 & R_P (+), W_P (+), CL (+), HH (-), OTH (-) & Rurality \\
\hline F2 & M_L (+), F_L (+), R_L (+) & Subgroup Literacy \\
\hline F3 & F_P (+), S_R (+) & Female Concentration \\
\hline F4 & SC (+), ST (-) & Social Backwardness \\
\hline F5 & AL (+), CL (-) & Agricultural Poverty \\
\hline
\end{tabular}

\section{Subgroup Literacy Index}

Spatial variation of subgroup literacy index has been illustrated in Figure $3 b$. It is imperative to understand the distribution of individual aspects of the component to understand the factor scores. Mean rural literacy at tehsil level is 60.96 percent with tehsil level figures ranging from 26.58 percent in Kotra (Udaipur district) to 79.12 percent in Behror (Alwar district) tehsils and a standard deviation of 7.37 percent. Mean Male literacy in the region is 77.28 percent with a minimum of 36.43 percent in Kotra and maximum of 91.10 percent in Behror and standard deviation is 7.22 percent. In majority of the tehsils male literacy is on higher end of the scale. Wide disparity exists in male and female literacy in the State with mean female literacy being remarkably low at 48.6 percent with high spatial variability (standard deviation of 9.02 percent). Kotra ranks lowest in female literacy too (16.49 percent) while the maximum occurs in Jaipur tehsil (76.13 percent) which is also not very high. Relatively lower factor loading of $F_{-} L$ as compared to $M \_L$ and $R \_L$ underlines relatively lower female literacy in areas of high male and rural literacy. Positive factor scores (especially $>1$ ) of the component imply high level of rural, male and female literacy in the tehsil and negative scores are indicative of low literacy among these subgroups. Spatial distribution of factor scores of the index reveals three salient characteristics:

1. All three aspects of literacy are highly spatially correlated.

2. Wide regional variation exists in literacy levels among all three population subgroups.

3. High and low literacy areas are highly spatially concentrated and markedly co-terminus with district boundaries.

A clear north-east and west-south divide marks the distribution of the component. A contiguous region in northern, north-eastern and eastern parts of the State scores moderate to high on the component comprising tehsils of northern, north-eastern districts and major part of 
Hadoti region. Central part of Udaipur district and eastern parts of Chittaurgarh and Pratapgarh districts and a small pocket across south eastern Jodhpur, Sojat (Pali district) to Beawar-Bhim (Ajmer and Rajsamand districts respectively) also score moderate to high. Other than these, all the tehsils of northern and north-eastern districts form a contiguous pocket of highest scoring region. Another notable pocket of highest scores comprises a contiguous group of tehsils including Digod and Sangod of Kota district, Antah and Baran of Baran district and Khanpur of Jhalawar district. On the other hand, a continuous belt comprising tehsils of Bikaner, Jaisalmer, Barmer, Jalore, Sirohi and western part of Udaipur districts in western and south- western Rajasthan scores lowest on the index.

\section{Female Concentration Index}

The third component is linearly positively related to proportion of females in total population of the tehsil. Female population in individual tehsils ranges from 45.33 percent in Jaisalmer tehsil (S_R = 829) to 51.21 percent $\left(S \_R=1050\right)$ in Kumbhalgarh tehsil of Rajsamand district with a mean of 48.24 percent and standard deviation of 1.13 percent. Distribution of factor scores of the index has been shown in Figure 3 (c). Visual comparison of distribution of these scores with distribution of scores of Rurality Index and Subgroup Literacy Index suggests a clear negative correlation between female concentration and former two.Tehsil scoring high on the latter have lower female concentration. A distinct north-south belt encompassing Churu, Jhunjhunu, Sikar, Nagaur, Pali, Jalore, Tonk, Ajmer, Rajsamand, Bhilwara, Chittaurgarh, Udaipur, Dungarpur, Banswara and Pratapgarh districts scores positively on the index. Notably a contiguous region comprising eastern part of Pali, Rajsamand, western part of Bhilwara and major part of Chittaurgarh district scores highest on the index thereby implying larger proportion of females in the total population of the tehsils. Lowest scoring tehsils are clustered in western and eastern parts of the State especially Jaisalmer and parts of Barmer, and Bikaner districts in the west, and Dhaulpur, Bharatpur and Karauli districts in the east. Except for Jhunjhunu and Sikar districts, and a contiguous patch of tehsils partly covering Kota, Baran and Jhalawar districts, areas of high female concentration have low levels of literacy.

\section{Social Backwardness Index}

The index has high positive loading of SC and equivalent high negative loading of ST. Thus, positive scores of the component indicate relatively high proportion of SC population in the tehsil while high negative scores indicate concentration of ST population. Proportion of SC population in the State varies from a minimum of 0.74 percent in Kotra (Udaipur district) to 48.11 percent in Karanpur (Ganganagar district). SC population is evenly distributed across the State with SC proportion being 10 to 30 percent in majority of the tehsils. Highest SC concentration occurs in northern districts. Southern Rajasthan, particularly Udaipur, Banswara, Dungarpur and Pratapgarh districts are an exception with negligible proportion of SC population. Distribution of ST population in the State is highly skewed with high spatial variability across the tehsils. Maximum concentration occurs in southern Rajasthan and Kishanganj and Shahbad tehsils of Baran district. In tehsils located in Udaipur, Dungarpur, Banswara and Pratapgarh districts ST population forms as high as 75 percent of total population. Moderate concentration occurs in eastern Rajasthan too predominantly eastern tehsils of Jaipur district, Dausa, Karauli, Sawai Madhopur and Dhaulpur district. ST distribution is negligible in remaining part of the State upto as low as less than 1 percent in 54 tehsils predominantly located in Ganganagar, Hanumangarh, Bikaner, Nagaur, Churu, Alwar and Bharatpur districts. Figure 3 (d) shows distribution of factor scores for the index. The index scores high in major part of the State excluding ST dominated region of extreme south and eastern Baran district. Map comparison with distribution of literacy does not reveal any direct correspondence with SC distribution but literacy rates are invariably low in ST concentration areas.

\section{Agricultural Poverty Index}

Agricultural labourers constitute the most neglected class in Indian rural sector lying in lowest income strata. They belong to depressed social classes, are unskilled and lack any training for alternative employment, are unemployed for major part of the year, are unorganised and ignorant. This component relates positively with agricultural poverty. High scores of the index (Figure $3 e$ ) show clear spatial concentration. Three contiguous regions of concentration comprise tehsils of Ganganagar and western part of Hanumangarh disricts in the north, southern Nagaur, Pali, Sirohi, Udaipur, Dungarpur, Banswara and Pratapgarh in south-central 
Rajasthan and almost entire Hadoti region. Except northern part of Ganganagar district comprising Karanpur, Padampur, Sadulshahar and Ganganagar tehsils - regions scoring high on the index lag behind in literacy.

Figure 03: Factorial ecology of the study area (a) Rurality index (b) Subgroup literacy index (c) Female concentration index (d) Social backwardness index, and (e) Agricultural poverty index

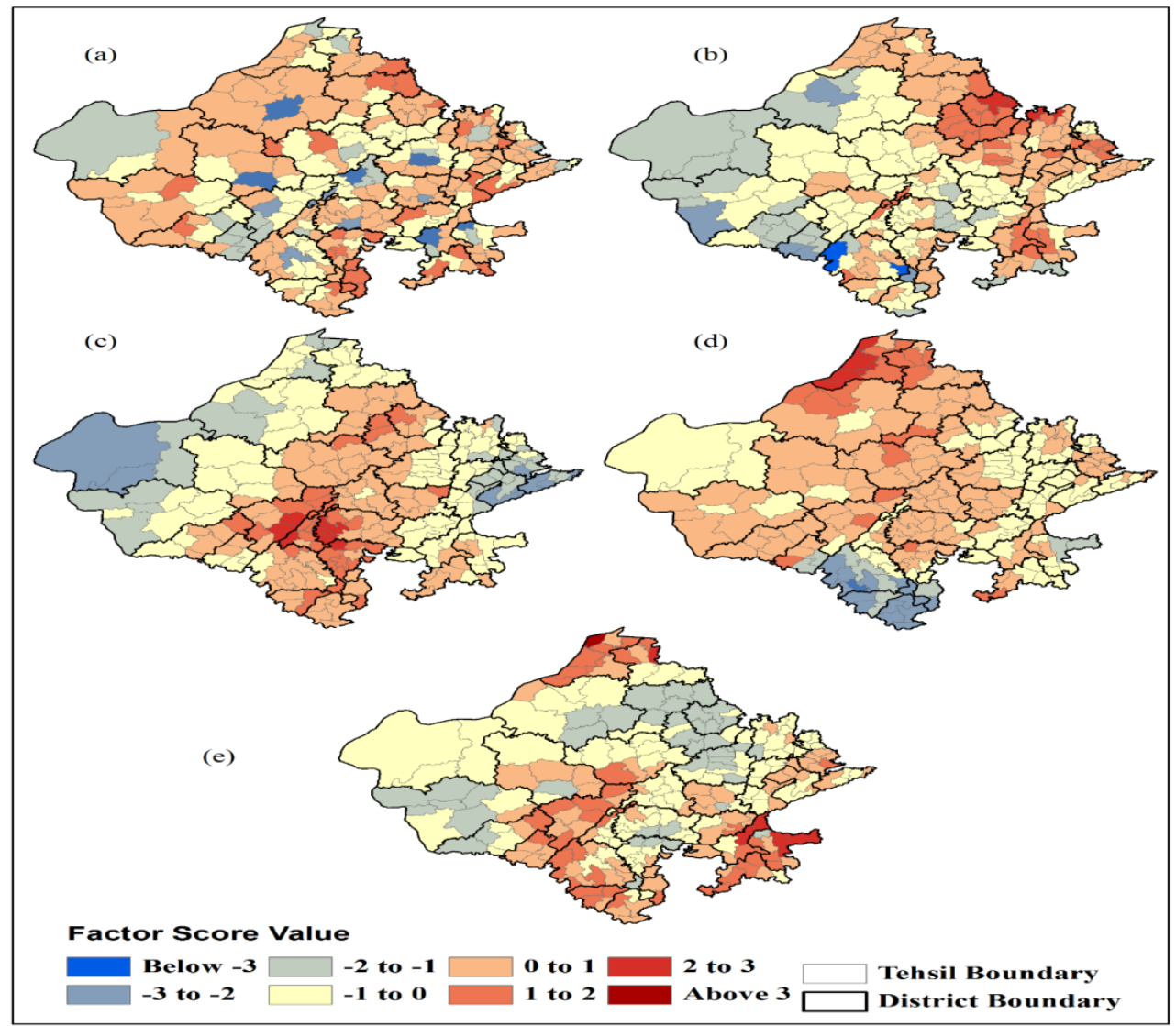

\section{Socio-economic Correlates of Literacy}

Table 4 shows the results of multiple regression of tehsil wise total literacy on the five socioeconomic indices. The five indices almost completely explain the variability in total literacy (Adjusted $R^{2}=98.8$ percent). The literacy status is positively associated with the subgroup literacy and social backwardness indices. On the other hand, rurality, female concentration and agricultural poverty are negatively associated with literacy. The strongest explanatory variable is F2 implying thereby that in high literacy areas gender as well as rural-urban disparity in literacy is low and literacy rate among all the subgroups is high. Excluding F2, the coefficient of determination (Adjusted R2) of the remaining four indices is 19.4 percent. Low literacy rates predominantly prevail in rural areas, among female population and agricultural laborers and cultivators alike. Literacy also correlates significantly with social backwardness. Scheduled tribe dominant areas are particularly lagging in literacy levels.

Table 04: Results of Multiple Regression of Total Literacy Rate on Socio-Economic Indices

\begin{tabular}{|c|l|c|c|}
\hline \multicolumn{2}{|c|}{ Socio-economic Indices } & Intercept (Constant) & Regression Coefficients \\
\hline F1 & Rurality Index & 63.379 & \\
\hline F2 & Subgroup Literacy Index & & -3.050 \\
\hline F3 & Female Concentration Index & & 6.997 \\
\hline F4 & Social Backwardness Index & & -1.392 \\
\hline F5 & Agricultural Poverty Index & & 1.215 \\
\hline
\end{tabular}

\section{Conclusion}

Rajasthan has a long way to go to reach a satisfactory level of literacy. The picture is gloomy in major part of the state and marked regional divide in literacy rates underlines gross imbalance in level of human resource development and poor economic structure. Low explanatory power of socio-economic indices (excluding Subgroup Literacy Index) underlines low literacy in all social and economic strata alike. Regions of high total, rural as well as urban literacy are 
spatially concentrated in northern and north-eastern part of the State whereas the status in remaining region specifically the tehsils of districts located in western, south-western and southern Rajasthan is dismal. These cold spots of low literacy deserve immediate attention in future policy plans. Tailored policies drafted in accordance with the local conditions are urgently required. Spatial statistical tools and interactive dynamic mapping enabled in GIS environment is imperative to identify the priority areas categorically as it helps to uncover the cold spots which may not be apparent by mapping simple percentages. Advanced statistical tools as factor analysis enable analysis of literacy patterns in light of wider socio-economic contexts and also the socio-economic-demographic groups which require immediate attention. Policy making should thus be guided by informed decisions based on robust geospatial and statistical analysis. Further research at local scales is required to identify region specific factors underlying the observed patterns. Geographically weighted regression implemented in GIS can be used to unravel the local relationships between literacy rates and socio-economic determinants. Additional variables as drop-out rates in schools, infrastructural facilities, accessibility, government policies, public fund allocation and gender bias could further help to understand the patterns so observed.

Acknowledgement: We thank Directorate of Census Operations Rajasthan and Census of India for providing us the Primary Census Abstract (PCA) data for 2011.

\section{References}

1. Aghajani, M.A., Dezfoulian, R.S., Arjroody, A.R. and Rezaei,M. (2017) Applying GIS to Identify the Spatial and Temporal Patterns of Road Accidents Using Spatial Statistics (case study: Ilam Province, Iran), Transportation Research Procedia, Volume 25,Pages 21262138, ISSN 2352-1465.

2. Ansari, S.M. \& Kale, K.V. (2014) Methods for Crime Analysis Using GIS. International Journal of Scientific \& Engineering Research, Volume 5, Issue 12, ISSN 2229-5518.

3. Census Report of 2011 Published by Directorate of Census Operation in Rajasthan State, Rajasthan.

4. Chand, Prem (2015) "Spatial Patterns of Literacy in Rajasthan 2011: A Geographical Perspective", Asia Pacific Journal of Research, vol.-1, Issue XXXI, pp.11-18.

5. Chitragar, S. and Hurakadli, S.M. (2013) "Gender Disparities in Literacy Pattern in the Malaprabha Command Area, Karnataka State - A Geographical Approach", Global Research Analysis, vol.2, Issue 10, pp.36-41.

6. ESRI, "GIS Best Practices for Social Sciences", July, 2009

7. Jalan, S. (2015) Electoral Delimitation of Reserved Constituencies: Some Observations Regarding Delimitation of Scheduled Tribe Constituencies in North East Rajasthan, Annals of Rajasthan Geographical Association, Vol. 32, pp. 1-16

8. Kundu, A. and Rao, J.M. (1982) "Inequality in Educational Development: Issues in Measurement, Changing Structure and its Socio-Economic Correlates with Special Reference to India", Paper Presented at Regional Workshop on Long Term Educational Planning, NIEPA, New Delhi

9. Mitchell, Andy (2009) "The Esri Guide to GIS Analysis, vol.2: Spatial Measurements \& Statistics", Esri Press, Redlands, California.

10. Ram, Deva (2014) "Sex and Residence-wise Analysis of Literacy in Rajasthan", Quest Journals, Journal of Research in Humanities and Social Science, vol.2, Issue3, pp.23-28.

11. Sangwan, S., Mahima, Singh, B. and Sangwan, R.S. (2014) "Spatio-Temporal Dimensions of Fertility in India: A Perspective on Rural - Urban Disparity", The International Journal of Humanities \& Social Studies, Vol.2, Issue 2, pp.93-104.

12. Sharma, Madhulika (2015) "Inter-District Disparities in Literacy with Reference to Gender and Location: A Study of Rajasthan", Indian Journal of Applied Research, vol.5, Issue 3,

13. Shekhawat, S, Jalan, S. \& Joseph, M. (2011) Geospatial Analysis of Ground Water Quality and Associated Health Problems in Dudu Block, Rajasthan. Proceedings of 4th International Conference on HealthGIS 2011.

14. Singh, P.V., (2014) "Socio-Geographical Phenomena of Women's Literacy in India", Scholarly Research Journal for Interdisciplinary Studies, vol-2/15.

15. Zaidi, S.M.I.A.: "Measures of Inequalities" accessed online at www.educationfor allinindia.com. 